\title{
Processing enhanced the nutritional contents of Enterolobium cyclocarpum seeds
} Falola, O. O.

Federal college of Animal Health and Production Technology, PMB 5029, Ibadan, Oyo state, Nigeria.

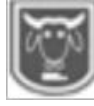

Abstract
Corresponding author: oyenikeolubunmi@yahoo.com

$$
+2348056266636
$$

An experiment was carried out to determine the effects of different methods of processing on the nutritional and anti-nutritional contents of Enterolobium cyclocarpum seeds. The seeds were harvested and processed into four different treatments: T1 (raw), T2 (boiled), T3 (Soaked), and T4 (roasted). The seeds were later ground in hammer mill and taken to laboratory to determine crude protein $(C P)$, crude fiber $(C F)$, ether extract $(E E)$, ash, nitrogen free extract (NFE). Mineral contents such as calcium (Ca), phosphorus (P), magnesium ( $\mathrm{Mg}$ ), and sodium ( $\mathrm{Na}$ ) were also analysed. Some anti-nutritional factors such as saponnin, tannins, oxalate and phytate were also determined. Data obtained were subjected to analysis of variance. It was observed that crude protein of the treated seeds were significantly higher than the raw. T2 recorded the highest (36.31\%) followed by T3 (34.52\%) and T4 (33.24\%) while the lowest was observed in T1 (19.33\%), Ether extract followed the same trend. Crude fiber ranged from $15.92 \%$ in $\mathrm{T1}-2.42 \%$ in T2. Results obtained for calcium (8.90-6.00\%), magnesium (5.45-4.85\%), sodium (2.38-1.69\%) and phosphorus (2.85-1.36\%) were significantly higher in Tlamong the treatments. Oxalates (0.19-0.11\%), phytates (0.33-0.19\%), tannin (0.05-0.02\%), and saponnin (0.41-0.33\%) were observed to be significantly lower in the processed seeds than the raw. It can be concluded boiling had significant increase in protein content and decrease in crude fiber content of the seeds.

Keywords: Enterolobium cyclocarpum seeds, nutrients, anti-nutrients and mineral contents.

\section{Introduction}

The prohibitive cost of concentrate diets for ruminants in the tropics during the dry season necessitates continuous search for less expensive and high nutritive feedstuffs. Unconventional protein sources from browse trees, legumes and seeds of trees were reported to be sustainable for ruminants in the tropics. Enterolobium cyclocarpum is a mimosaceous legume tree, found in the deciduous lowlands forest (Janzen, 1981). The legume is easily established and fast growing to maturity over a period of time than most common leguminous trees in Nigeria. In a preliminary study, Ezenwa (1998) recommended the legume to be suitable for use in intensive feed garden in southwestern Nigeria, being fast and luxurious in growth. Enterolobium cyclocarpum has large, thickened, contorted, indehiscent pods which resemble an ear in form. The pods contain sugary dry pulp which is highly palatable and nutritious. Pods fall from the tree gradually at the end of the dry season for over a period of two months, thus spreading the availability of pods for livestock. According to Janzen (1981), its fruits are avidly eaten by free- ranging horses, suggesting its utilization for livestock. Browse plants and their seeds are available in the off season but most of them are less beneficial to livestock as they contain antinutritional factors. Anti-nutritional factors are organic compounds which when present in a diet, may adversely affect the health and growth of animal by interfering 
with normal feed utilization and preventing the absorption of nutrients from the diet. Hence the need for processing in order to make them suitable for livestock feed. The study was aimed to determine the effects of different methods of processing on the nutritional contents of Enterolobium cyclocarpum seeds.

\section{Materials and methods}

Enterolobium cyclocarpum pods were harvested at Moor-plantation environment Ibadan, and the seeds were removed from the pods manually. The seeds were divided into four treatments: T1 (raw), T2 (boiled) $1 \mathrm{~kg}$ of the seeds was poured into boiling water for 40 minutes, drained and sundried for 3 days. In theT3 (soaked), $1 \mathrm{~kg}$ of the seed was soaked in 2 liters of water for 24 hours, drained and sundried for 3 days. For $\mathrm{T} 4$ (roasted), $1 \mathrm{~kg}$ of the seed was roasted in dry frying pan on a hot plate at $60^{\circ}$ for 45 minutes. All the treated seeds were separately ground in hammer mill for consequent analysis.

\section{Chemical analysis}

Known weight of each sample was oven dried at $65^{\circ} \mathrm{C}$ to a constant weight for dry matter determination (DM). Proximate analysis; crude protein, crude fibre, ether extract and ash were analysed according to the standard methods of (AOAC, 1995). Quantitative determination of tannins, saponnins, oxalates, and phytates were also carried out in triplicates, using the method of AOAC (1995). After ashing of samples in a muffle furnace at $550^{\circ} \mathrm{C}$, mineral analyses of calcium and potassium were determined using Atomic Absorption Spectrophotometer while sodium was read in flame photometer and phosphorus was read in flame spectrophotometer.

\section{Statiscal analysis}

All the data obtained were subjected to analysis of variance (ANOVA) using SAS, (1998), Means were compared using Duncan (1955) option of same software.

\section{Results and discussions}

Table 1 shows the proximate composition of raw and processed Enterolobium cyclocarpum seeds. The crude protein ranged from $36.31-29.33 \%$, processing increased the $\mathrm{CP}$ contents while crude fiber was reduced, the $\mathrm{CF}$ values ranged from $15.39-2.42 \%$, T1 recorded the highest while the least was observed in T2. Etherextracts follows the same trend, it ranged from 5.66-2.20\% the highest was observed in $\mathrm{T} 1$ while the lowest was observed in T2.

Table 1: Proximate composition of processed Enterolobium cyclocarpum seeds

\begin{tabular}{lllll}
\hline Parameters & T1 $(\mathrm{raw})$ & T2 $($ boiled) & T3 (soaked) & T4 (roasted) \\
\hline Dry matter & 92.13 & 91.63 & 91.85 & 92.07 \\
Crude protein & 29.33 & 36.31 & 34.52 & 33.24 \\
Crude fiber & 15.39 & 2.42 & 3.00 & 9.26 \\
Ether extract & 5.66 & 2.20 & 3.12 & 3.80 \\
Ash & 4.35 & 3.50 & 3.85 & 3.79 \\
NFE & 47.36 & 50.87 & 41.98 & 43.78 \\
\hline
\end{tabular}

Table 2 shows the mineral contents of the raw and the processed seeds. Processing reduced the level of mineral composition of the seeds. The range observed for $\mathrm{Ca}(8.90$ $6.00 \%), \mathrm{Mg}(5.45-4.85 \%), \mathrm{Na}(2.38-$ $1.69 \%)$ and $\mathrm{P}(2.85-1.36 \%)$, T1 recorded the highest and significantly higher than values obtained for T2, T3and T4 among the treatments. The values obtained for $\mathrm{Ca}$, $\mathrm{Mg}, \mathrm{Na}$ and $\mathrm{P}$ were within the range recommended for maintenance, lactating and non-lactating goats (NRC, 1981). 
Falola

Table 2: Mineral contents (\%) of raw and processed Enterolobium cyclocarpum seeds

\begin{tabular}{llllll}
\hline Parameter & T1 $(\mathrm{raw})$ & T2(boiled) & T3(soaked) & T4(roasted) & \pm SEM \\
\hline Calcium & $8.90^{\mathrm{a}}$ & $6.90^{\mathrm{b}}$ & $6.00^{\mathrm{bc}}$ & $6.10^{\mathrm{bc}}$ & 2.90 \\
Magnesium & $5.45^{\mathrm{a}}$ & $5.32^{\mathrm{b}}$ & $4.85^{\mathrm{c}}$ & $5.27^{\mathrm{b}}$ & 0.60 \\
Sodium & $2.38^{\mathrm{a}}$ & $2.16^{\mathrm{b}}$ & $1.69^{\mathrm{c}}$ & $2.16^{\mathrm{b}}$ & 0.69 \\
Phosphorus & $2.85^{\mathrm{a}}$ & $2.59^{\mathrm{b}}$ & $1.36^{\mathrm{c}}$ & $2.30^{\mathrm{bc}}$ & 1.49 \\
\hline ISEM = standard error of mean, a,b,c means same superscripts on the same row are not significantly different P > 0.05
\end{tabular}

Presented in Table 3 are the anti-nutritional factors of both the raw and processed seeds. It was observed that processing reduced the level of anti-nutritional contents of the seeds. Oxalates ranged from $0.19-0.11 \%$ showed no significant differences among $\mathrm{T} 1, \mathrm{~T} 2$ and $\mathrm{T} 3$. The same trend was observes for phytates $(0.33-0.19 \%)$, tannin $(0.05-0.02 \%)$ and saponnin $(0,41-0.33 \%)$. The level of oxalates observed here is unlikely to pose toxicity problems, since it was below $2-5 \mathrm{~g}$ recommended as the threshold (Oke, 1969). Oxalate affects Ca and $\mathrm{Mg}$ metabolism (Onwuka,1983) but ruminants can consume considerable amounts of high oxalate plants without adverse effects due principally to microbial decomposition in the rumen.(Oke,1969).
The knowledge of the phytate level in feeds is necessary because high concentration can cause adverse effects on the digestibility of minerals (Nwokolo and Bragg, 1977). Phytate forms stable complexes with $\mathrm{Cu}^{2+}$, $\mathrm{Zn}^{2+}, \mathrm{Co}^{2+}, \mathrm{Mn}^{2+}, \mathrm{Fe}^{2+}$ and $\mathrm{Ca}^{2+}$. Saponins reduce feed intake, and uptake of certain nutrients including glucose and cholesterol. From the levels obtained in this study it is not likely that the saponnin content of Enterolobium cyclocarpum seeds will affect its nutritional potentials to any significant extent. The level of tannin which adversely affect digestibility in sheep and cattle is between 2\% and 5\% (Diagayete and Huss; 1981). Goats are known to have threshold capacity of about 9\% dietary tannin (Natis and Malachek, 1981).

Table 3:Anti-nutritional contents (\%) of raw and processed Enterolobium cyclocarpum seeds

\begin{tabular}{llllll}
\hline Parameters & T1(raw) & T2(boiled) & T3(soaked) & T4(roasted) & \pm SEM \\
\hline Oxalate & $0.19^{\mathrm{a}}$ & 0.12 & 0.11 & 0.11 & 0.07 \\
Phytate & $0.33^{\mathrm{a}}$ & 0.20 & 0.19 & 0.19 & 0.14 \\
Tannin & $0.05^{\mathrm{a}}$ & 0.03 & 0.02 & 0.02 & 0.03 \\
Saponin & $0.41^{\mathrm{a}}$ & 0.34 & 0.34 & 0.33 & 0.08 \\
\hline 士SEM = standard error of mean, a,b,c means same superscripts on the same row are not significantly different P>0.05
\end{tabular}

\section{Conclusion}

The study has shown that different processing methods increased availability of crude protein contents, reduced crude fiber, mineral and anti-nutritional contents of Enterolobium cyclocarpum seeds.

\section{References}

AOAC, 1990. Official Methods of Analysis. $15^{\text {th }}$ Edition Association o f A n a l y t i c a 1 Chemists.WashIngton D.C, USA.

Diagayette, M. and Huss, W. 1981. Tannin contents of African pasture plants. Effects on analytical data and invitro digestibility. Animal Research and Development 15; 7990

Duncan, D. B. 1955. Multiple range and multiple F-test. Biometics, 11: 142.

Ezenwa, I. 1998. Preliminary evaluation of suitability of Enterolobium cyclocarpum for use in intensive feed garden in southwestern Nigeria. Agrofor. Sys 44: 13-19 
Processing enhanced the nutritional contents of Enterolobium cyclocarpum seeds

Janzen, D. H. 1981. Enterolobium cyclocarpum seed passage rate and survival in horses, Costa Rican Pleistocene seed dispersal agents. Ecology, 62: 593-901.

Natis, A. S. and Malachek, J. C. 1981. Digestion and utilization of nutrients oak browse by goats .Journal of Animal Science 52; 283-288.

NRC, 1981. Nutrients requirement of goat; Angora dairy and meat goat in temperate and tropical continent.Nutrient requirement of Domestic animals.
Nwokolo, E. N. and Bragg, B. B. 1977. Influence of phytic acid and crude fiber on the availability of minerals from protein supplements in growing chicks. J. Animal science., $57 ; 475-477$.

Oke, O. L. 1969. Oxalic acids in plants and in nutrition ; world review of Nutrition and Dietetics 10;263303.

Onwuka, C. F. 1983. Nutritional evaluation of some Nigeria browse plants in the humid tropics. Ph.D Thesis University of Ibadan, Ibadan, Nigeria.

SAS, 1998. Statistical analytical system institute, SAS/STAT User's guide statistical, SAS Institute, Cary. North Carolina, USA.

Received: 2nd October, 2017

Accepted: 30th November, 2017 